811.163.1'367

811.163.41'36"18"

https://doi.org/10.18485/sj.2018.23.1.27

ТОМИСЛАВ М. МАТИЋ

Универзитет у Београду

Филолошки факултет
Оригинални научни рад

Примљен: 04. 01. 2018.

Прихваћен: 29. 01. 2018.

\title{
О РЕДУ РЕЧИ КАО СПЕЦИФИЧНОМ СИНТАКСИЧКОМ РЕПРЕЗЕНТУ ЈЕЗИКА ХІХ ВЕКА У ГРАМАТИЦИ ЦРКВЕНОСЛОВЕНСКОГ ЈЕЗИКА Е. ЈОВАНОВИЋА ИЗ 1851. ГОДИНЕ
}

У раду ће бити представљен и анализиран и теоријски размотрен ред речи као специфичан синтаксички репрезент језика XIX века у Грамайици ирквенословенског језика Евгенија Јовановића из 1851. године. Покушаћемо да утврдимо у којој мери се ауторови ставови подударају са синтаксичким карактеристикама славеносрпске епохе, као и у којој мери се у њима могу идентификовати синтаксичке особености српског народног језика тога времена, а посредно и савременог језичког израза.

Кључне речи: ред речи, синтакса, (реченица, синтагма, атрибут, глагол) црквенословенски језик, славеносрпски језик, српски језик, славенски језик.

Говорећи о науци о језику и стању у српској граматици с краја XIX века Стојан Новаковић у својој посланици СКА (Новаковић 1888: 35-36) између осталога истиче:

Излишно је и доказивати да је познавање нашег језика напредно по аналитичкој, гласовној или обликовној страни, али да је назадно и да му још много рада треба по синтактичкој и стилистичкој страни. [...] Синтакса о речима, именицама, придевима, заменицама и бројевима, синтакса о глаголима, о њиховим значењима, о њиховим сла-

*t.matic@yahoo.com 
гањима, о њиховим додацима или допунама, о њиховим простим или сложеним облицима, синтакса о прилозима и предлозима, синтакса о реду речи и реченица [Истакао Т.М.], није ни започета да се обрађује.

Синтакса, а са њом и ред речи, врло касно је постала предмет озбиљнијих научних интересовања у српској лингвистици - прва студиознија (монографска) синтаксичка проучавања везују се за другу половину XIX века. ${ }^{1}$ Ни у њима, чини се, није посвећена адекватна пажња реду речи као специфичном синтаксичком проблему уопште, а нарочито у време настанка тих студија. Тек ће Пера Ђорђевић у својој приступној беседи академији наука „О реду речи у српском језику” из 1898. године описати стање у српској вуковској реченици XIX века, на корпусу народне књижевности. Свакако најпрепознатљивија студија о реду речи у савременом српском језику је докторска дисертација Љубомира Поповића „Ред речи у савременом српскохрватском језику” из 1972. године, прерађена и објаљена (у два издања, 1997. и 2004. године) под насловом „Ред речи у реченици”.

Наше истраживање у овом раду усмерено је на граматичку литературу која претходи Новаковићевој оцени из увода рада. Показало се да она не важи у целини. Од такве његове констатације барем делимично одступају поједине граматике српског језика (или ког другог језичког узуса тога времена) већ с краја XVIII и из прве половине XIX века, у којима се о реду речи расправља унутар дела посвећеног синтакси, уз синтаксу променљивих врста речи или

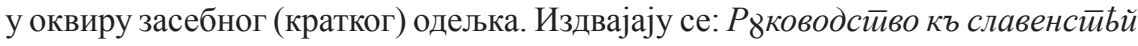
граммайіщь, Аврама Мразовића из 1794, Славенска граммайіка, Георгија Захаријадеса из 1832, Граммайіка сербска, Милована Видаковића из 1838. године.

Граммайїка церковно-славАнскагш Азыка ученог Евгенија Јовановића прва је граматика у нас у којој се реду речи приступа студиозно и на већем броју страна, где се разрађују и разрешавају препознатљиве синтаксичке инверзије епохе и у којој се ред речи не посматра само у морфосинтаксичком, већ и у ширем синтаксичком и стилистичком контексту.

Евгеније (Јефтимије) Јовановић је завршио богословију и студирао филозофију и права. Био је епископ горњокарловачки, наследник Лукијана Мушицког, али за разлику од њега искључиви противник Вукове реформе. Стога је очекивано што своју граммайїкв церковно-славАнскагш Азыка штампа црквеном ћирилицом. На крају увода, у којем указује зашто је боље и исправније чувати словенски језик као званични језички стандард, Јовановић граматику дели на двь еА главныл часиии: Правоглаголанїе и Правоиичсаніё

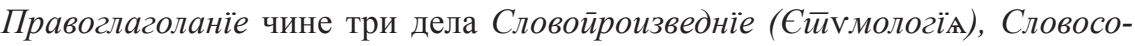
чиненїе (Сvнийац̆їсь) и Слоговдаренїе (Просшдї̈). Друга глава, о синтакси,

${ }^{1}$ Види: Даничић 1858; Бошковић 1864; Новаковић ${ }^{2} 1870 ;$ Новаковић ${ }^{4} 1880$ : Живановић 1889. 
обрађује се веома опширно, на преко 130 страна. Сама дефиниција синтаксе је у приличној мери слична са претходним дефиницијама у граматикама: Словосочиненіе естиь частиь Граммайїки иооказываючал йравила, каковымь

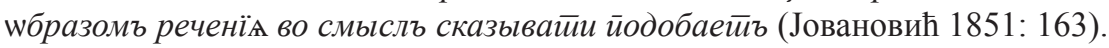

Први део Словосочиненї̈ осмишљен је и представљен као приказ синтаксе појединачних врста речи, при чему се, изненађујуће, безмало једнака пажња посвећује синтакси променљивих (именице, придеви, бројеви, заменице, глаголи и партиципи) и непроменљивх врста речи (прилози, предлози, везници и речце), а кроз веома велики број примера који потврђују сваку синтаксичку особеност која се датим правилом објашњава.

Други део, Раздьленїе вйорое, С̄ йослеьдованиіи реченій, доноси нам изузетно интересантна Јовановићева размишљања и експлицитну разраду појединих синтаксичких проблема који се директно тичу реда речи у славенском језику, тачније у одређеном књижевно-језичком стандарду у развоју српског језика.

Потребно је на почетку анализе расправе о реду речи укратко предочити ауторов став о пожељном језичком моделу у Срба, утврдити његов став према црквенословенском језику, затим према рускословенском и славеносрпском и на крају и према народној речи, односно према српском језику вуковског типа. Аутор насловљава своју граматику црквенословенском, готово доследно у тексту граматике језик назива славенским (славенскій), дидактички примери којима се потврђују правила или приказују изузеци од њих узимани су из дела изразито религијског карактера и веома прецизно су корпусно одређени (Онъ же : Не ббснуюса, рече, державный Фистие, но исиины глаголь вбщаю. Дьан. 26, 24. 25.). У Встияйленїю въ славенсквю граммайїку, залаже се за доследну употребу славенског језика у свештеним књигама, а наглашава и његову корист за српске писце тога времена:

Къ томя нашъ Азыкъ сербскїй безъ славенскагш есть sьлw шскяденъ; ш̄к8д8 писа-

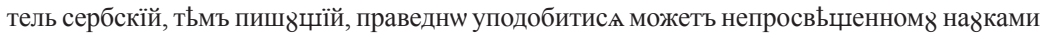
человькв. [...] Такш и сербскїй писатель, лишенъ нұждныхъ реченій, приняжденъ бываетъ изъ славенскагш, или изъ чджихъ Азыкшвъ взимати А, да бы совершеннш изАснитисл возмоглъ. Къ коем8 же Азык8 праведнБе и природнБе, нежели славенском8, нкш корени своем8, притечи должен? (Јовановић 1851: 1-2)

Из свега овога следи да се аутор, бавећи се анализом славенскога језика, у ствари бави анализом црквенословенског језика или тачније анализом језика црквених књига свога времена.

Такође, Јовановић се на неколико места у граматици, како ћемо и видети даље у раду, на одређени начин ограђује од (синтаксичких) утицаја руског језика на језик превода свештених књига свога (новијег) времена, дистанцирајући се тиме суштински и од славеносрпског, као хибридне последице тих утицаја. С друге стране, када говори експлицитно о српском језику, доследно 
га, заједно са руским, посматра у ширем контексту у односу на славенски језик, наглашавајући притом препознатљиве језичке карактеристике које их управо и нераскидиво везују за тај старији (јужно)словенски књижевни језик.

Могли бисмо, дакле, закључити да је Јовановићев славенски језик највероватније директни континуант црквенословенског језика, ослобођен синтаксичких утицаја руског (и немачког) језика и да га можемо посматрати као језик веома близак језику књижевности и науке XIX века заснованом на српском народном језику, у овом случају само корпусно снажно оивиченим ${ }^{2}$. За сам наш рад и није од пресудног значаја прецизно књижевнојезичко одређење језика који је предмет Јовановићеве граматике, већ много више чињеница да је аутор веома детаљно приступио синтаксичкој анализи језика, а посебно реду речи као једном од најкарактеристичнијих синтаксичких репрезената језика, односно реченице XIX века. На крају бисмо нагласили и неретки несклад између правила (начела) везаних за ред речи које аутор износи и примера који би требало да их потврђују, а с друге стране, нарочито, готово супростављеност између поменутих правила и Јовановићевог граматичарског метајезика.

На самом почетку одељка (§103) даје описну дефиницију реда речи:

Славенскій Азыкъ имать велик8, но не совершення свободя во разположенїи частей рьчи, то есть; въ немъ коеждо реченїе можеть помьченно быти тамш, идЬже имьетъ болшяю изразителность, сльдяА естественомя теченїю мыслей, а не условнымъ правилшмъ словоразположенїА (Јовановић 1851: 275).

Непосредно након тога аутор даје и примере који потврђују слободни ред речи у славенском језику. Унутар истог параграфа, у виду две напомене (иримьчанїв) расправља о богатству облика српскога језика. Говори о бројним примерима морфосинтаксичке синонимије и слободном реду речи у старијим фазама (књижевног) језика у Срба и наглашава да је, къ часиї̈о нашех словесностии, сербскій равнш ғакоже и россійскій мзыкъ, иродолженїе сый, ииакш

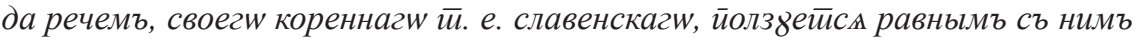
иреимдщесиивомъ (Јовановић 1851: 276). Увођењем оваквог вида синтаксичког и упоште језичког паралелизма између руског и славенског (српског) Јовановић само експлицира особине заједничке тим језицима, а наслеђене из ранијих фаза словенског језичког стандарда. Као што ће се видети и даље у тексту, он ту ни у ком случају не мисли на нама данас најпрепознатљивије трагове руског језика у синтакси славеносрпске епохе (синтагматске инверзије, постпонирање дела предиката и сл.), које су заправо кроз руски (рускословенски) у језик наших књижевника тога времена дошле из класичних језика. Аутор то наслеђено богатство из стиаријих (коренніхъ) језика између осталог види и у

\footnotetext{
${ }^{2}$ Чини се да славенским језиком аутор ипак одређује два различита књижевнојезичка узуса, црквенословенски језик (пре појаве редакција) и језик свештених књига свога времена (новији рускословенски језик).
} 
слободном реду речи у српској реченици. У другој напомени из овог параграфа се и на конкретним примерима превода (свештених) књига, те пресликавања морфосинтаксичких конструкција са грчког на српски језик, истиче огрешење о поменуто богатство језика.

У завршном делу ове напомене аутор износи веома интересантно запажање, за разумевање реда речи у славеносрпској епоси потенцијално изузетно значајно. Наиме, он истиче да су новији преводиоци тога времена, како би приближили стари језик народном говору и тиме га учинили разумљивијим својим савременицима, унели во церковнылы наши книги нбкойорах россійская жконченїя и шбраченї̈. Сїя ирричина естиъ несходсивва между рдкойисми и между ветихими и новыми изданїнми свяченныхъ книгъ, и иеогш ради не рбдкш

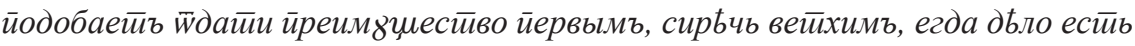
w йравильхь собстивеннш славенскагш дзыка (Јовановић 276-277). Овде се пак може наслутити горе поменути утицај руског језика на српски језик и српску реченицу. С циљем приближавања језика свештених књига савременицима, најчешће на лексичком плану, преводиоци су у језик уносили и неке морфосинтаксичке завршетке и синтаксичке обрте. Може се претпоставити да су такви синтаксички обрти и инверзије из језика књига са религиозним дискурсом касније улазили и у језик лепе књижевности, затим и у друге стилове српског језика тога времена. Ту се заправо огледа индиректни утицај немачког, а даље класичних језика, нарочито латинског, кроз руски (рускословенски) на синтаксу славеносрпске реченице, конкретно на ред речи у њој. Индикативно је да Јовановић препоручује употребу старијих форми, наглашавајући аутентичност славенског језика које оне носе у себи.

У наредном параграфу Јовановић експлицира како крупније, тако у фусности и ситније морфосинтаксичке и синтаксичке разлике између грчког и славенског језика. Наглашава на крају да се тешко може говорити о карактеру и особеностима славенског језика ван дискурса свештених књига, зане иррежде иревода вівлій славенскимъ Азыкомь никӣоже орїгїналнш не иичсаль (Јовановић 1851: 277-278).

У параграфу 105, у једанаест тачака, аутор даје веома детаљну разраду реда речи као специфичног синтаксичког репрезента српског језичког стандарда тога времена или, можда тачније, репрезента синтаксе (свештене) литературе свога времена. Прецизан предмет својих запажања најављује:

Глаголюще мы здъ w разположенїи частей рьчи славенскагш Азыка, не бядемъ повторАти правила обџа коемяждо Азык8 имұџемя свободное словоразположенїе, ғакови суть греческій и латїнскій, w ныхже во грамматїкахъ многш писано есть въ семъ wношенїи. Мы замътимъ въ кратцђ токмш нъкаА частнаА правила, принадлежацаА собственнш славенском8 Азыку (Јовановић 1851: 278). 
У првој тачки Јовановић истиче да се придеви у функцији конгруентног атрибута не удаљавају, раздвајају (не $\bar{w} \partial б л А ю \bar{u} и$ ) од своје именице, односно од центра синтагме. Наводи и неколико примера који то потврђују: Вcb.мъ даде сугдбы ризы.

У виду напомене, ипак, додаје да се у (новијим) свештеним књигама несумњиво могу наћи примери супротни овом правилу, те даје примере: у

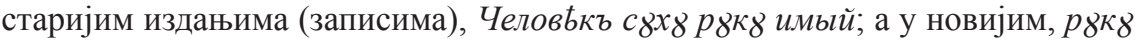
имый свх8. Након примера са разбијеним редоследом атрибута Јовановић истиче да је разлог томе синтаксичко решење у грчком оригиналу: йонеже сище сииоииъ во греческомъ йодлиннииь (исто: 278-279). Овде, дакле, имамо експлицирано подударање природног синтагматског реда речи у ауторовом језичком и граматичарском осећању са неутралним или природним редом речи у данашњем књижевном језику. Не мање важно је и то што се наглашава утицај грчког (класичног) језика на нарушавање аутентичног реда речи у новијим записима пишчева времена, чиме се на формирање претпостављене синтаксичке слике славеносрпског језика баца ново и конкретно светло. Данашња хипотеза да је синтакса славеносрпског језика формирана под снажним утицајем руске синтаксе, у којој се суштински огледају утицаји немачког језика, још даље, класичних језика, грчког и латинског, овде добија своје пионирске потврде.

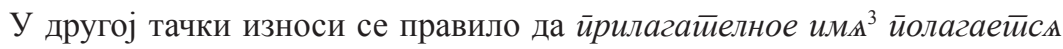
иредъ своімъ сұчестивииелнымъ, наийаче егда сказдмо естиь (Невинно вїно укоризненно же иї̈нстиво). Поново се ауторов став подудара са данашњим неутралним синтагматским редом речи. Ипак, истиче да и ово правило има доста изузетака, ййицы небесныл, корабли фарсійсӥй. Даље даје прецизне податке о употреби конгруентног атрибута у одређеним (религијским) текстовима; тако имамо податак да је у првој глави Јеванђеља по Луки конгруентна реч у односу на центар синтагме (именицу) постпонирана 73 пута, а да је у антепозицији у 20 примера. Упућује се, такође, и на примере да иста (придевска) лексема може бити коришћена у обе позиције, па тако во иеервомъ глась возкресномъ на госйоди воззахъ и сиӥховнь 22 обоюду шбрьйаейса (исто: 279). Евидентно је да је атрибутска постпозиција изразито чешћа у анализираним текстовима. Потенцијалне разлоге зашто аутор не објашњава такво стање, које противуречи правилу које је сам дефинисао, можемо тражити у чињеници да је раније у тексту упућивао на лоше стање у новијим преводима (мада се нигде конкретно у овој тачки не истиче да је реч о новијим преводима), те на утицај класичних језика на преводиоце тога времена. Ваља приметити да и Јовановић, иако прописује другачије, конгруентне речи, нарочито присвојне,

\footnotetext{
${ }^{3}$ У тексту ове напомене Јовановић наводи да се ово правило не односи само на придеве, већ и на остале врсте речи које се могу наћи у позицији конгруентног атрибута, сїе должно $u w$

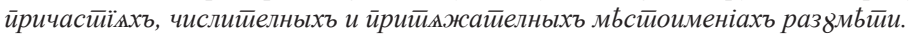


најчешће употребљава у постпозицији, чиме се показује очито неизбежан утицај руског (рускословенског) језика на језик писаца тога времена.

У трећој тачки аутор расправља о положају енклитичког облика повратне заменице себе - сл. Износи и правило да се она йосйавлялосл древле

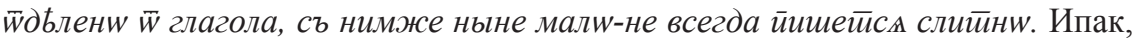
наглашава да се у најновијим издањима свештених књига може наћи много примера који су супротни овом правилу, наводећи примере за обе ситуације. И овде се може претпоставити утицај руског језика и његових морфосинтаксичких форми на језик литературе ауторова времена, те писање енклитичке форме повратне заменице заједно са глаголом. Наиме, у старијим српским рукописима повратни глаголи су доследно имали сложену форму, док се у руском језичком стандарду тада, а и данас, повратна заменица пише спојено са глаголом. Евентуално поновно прелажење на растављено писање могло би се тумачити као покушај ослобађања од утицаја руског језика.

Јовановић издваја још и писање $c$ я испред глагола у упитним реченицама, Госйоди, чиио са умножиша сйджаюұӥи ми?, распоред заменичких енклитика $\mu_{A}, \bar{u} \wedge, c \wedge, \boldsymbol{A}$ и $м u, \bar{u} u, c u$ у односу на предлог и глагол, као и примере (не)елидирања $c_{\text {A }}$ у (напоредним) глаголским конструкцијама,

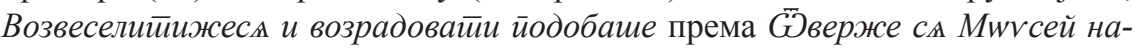
рицайи са сынъ дчере фарашновы (Јовановић 1851: 279-280).

Четврта тачка доноси нам на почетку примере плеонастичне употребе неких врста речи, те њихову евентуалну стилску или контекстулану оправданост. Тако за пример Богъ мұжа и жену сойвориль я естиь каже да то јесте излитесииво или йлеонасмъ, док за пример На рькахъ вавклшнскихъ, йамw сьдохомъ каже да то ньстиь йлеонасмъ, но енергїи ради 4 иовйорено. Насупрот плеонастичној употреби реченичних елемената наводи елипсу (еллїчїсь), дефинише је као изйдщеніе нькихъ реченій, ғаже обаче йодраздмьваюйсл, и наводи примере, $В ъ$ безводнбй; йо нейрохднбй; на ловньмъ (мбсйь). Након елипсе уводи две (реторичке) стилске фигуре за које је типична измена очекиваног, устаљеног реда речи, анаколут (Анаколдөонъ) и хистерон протерон

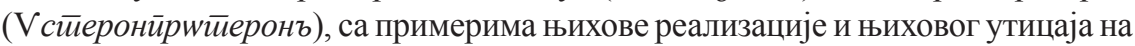
ред речи у реченици. ${ }^{5}$ Иако оне нису ни објашњене ни дефинисане, ни уведене на најјаснији начин, врло је значајно да истакнемо да је ово (вероватно) први покушај истовременог разматрања стилистичких и синтаксичких могућности

\footnotetext{
${ }^{4}$ Предлог ради Јовановић, како видимо и овде, доследно употребљава у постпозицији у односу на именицу.

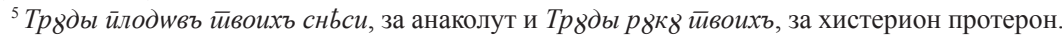
Занимљиво је истаћи да се ове фигуре неретко посматрају као подврсте елипсе, или, евентуално, када се дају примери за елипсу, у ствари описују анаколут и хистерион протерон (у Речнику књижевних йермина такав је случај). Слично томе, и Јовановић разматра примере ових двеју стилских фигура унутар дела посвећеног елипси.
} 
језичког израза с једне стране, и карактеристичног и тиме одређеног реда речи у реченици, с друге стране (исто: 280-281). Видели смо на почетку рада да на то на известан начин позива Стојан Новаковић, 37 година касније у својој Посланищи СКА.

У петој тачки говори се о евентуалној конгруенцији односних заменица (иже, ғаже, єже) са именицом на коју се односе. Наводе се примери за обе ситуације, док се само за заменице које конгруирају са својом именицом

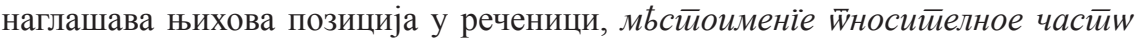

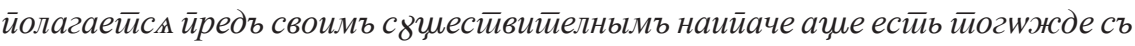
нимъ йадежа. Јовановић не дефинише разлику међу овим двема синтаксичким манифестацијама, већ остаје само на примерима, који их, опет, на недовољно јасан начин расветљују. У шестој тачки говори се о одричним придевским заменицама у предлошко-падежним конструкцијама и наглашава се да егда

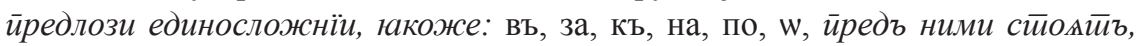

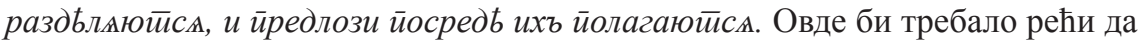
када говори о општим моделима употребе одричних заменица у овом одељку, Јовановић пре свега мисли на славенски (цркенослоенски) језик и ту наводи да постоје обрти у позицији предлога. У другом делу одељка он набраја те примере и у српском (народном, претпостављамо) језику и наглашава да је у њему употреба предлога испред заменице ретка. Ипак, пример којим то илуструје, Богъ сойворилъ міръ сей изъ ничегш, говори нам да аутор није био увек кадар да разлучи народни од црквенослоенског (па и славеносрпског) језика, будући да пример ни на једном граматичком плану не припада корпусу народнога говора (исто: 281-282).

У наредне две тачке говори се о карактеристичним позицијама предлога

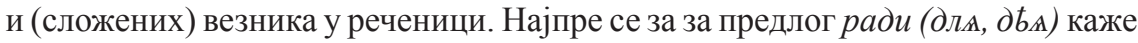

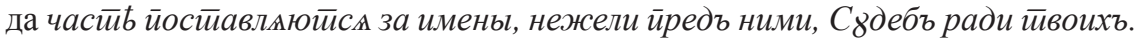
Ипак, даје и примере антепониране уоптребе предлога, која је у данашњем језику уобичајенија, не и једина, Ради благостии тивоея, госйоди. Предлог

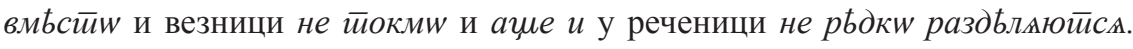
Оваква употреба сложених везника може имати континуанте и у савременом језику; за употребу сложеног предлога уместо (Еда въ рыбы мбсиио змӥю

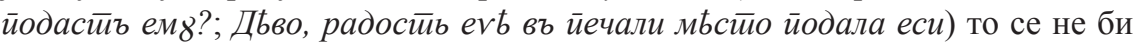
могло рећи (исто: 282).

Девета тачка подељена је на два дела. У првој се говори о позицији одређених везника у реченици. Тако се за везнике же, бо, ли, убш (quidem) прописује употреба ван иницијалне позиције, а после једне или више речи. За везнике $a$, но, зане, занеже, ғако, ибо, $\bar{ш} ь м ъ, ~ \overline{ш ь м ж е, ~ а щ е ~ к а ж е ~ д а ~ о н и ~}$ симонтиъ на началь своегш ирредложенїя, док за везнике убо, сирьчь, обаче наводи да могу бити и у иницијалној позицији, али и йосль нькоегш реченї̈. 
Као и у већини примера у овом делу расправе о реду речи Јовановић износи правило, често и примере који га потврђују (углавном и изузетке), али веома ретко правила објашњава и теоријски разрађује. Евидетно је да се о првој групи примера, којој се прописује ваниницијална употреба, може расправљати с аспекта њихове морфолошке класификације. За наведене примере би се пре могло тврдити да су речце (партикуле), и то већином енклитичког типа, чиме би се наведено њихово позиционирање у реченици потврдило. Речце као морфолошка категорија нису заступљене у граматичком терминосистему XIX века као јединствена граматичка категорија, каквом се данас схватају. У веома опширној и детаљној студији о граматичкој терминологији код Срба у XIX веку А. Ранђеловић посебан и обиман део посвећује и морфолошкој терминологији у наших граматичара тога времена (Ранђеловић 2016: 197-377). Међутим, не бележи податке о употреби термина за речце у анализираним граматикама и језичким студијама, те им сходно томе као морфолошкој класи не посвећује засебан део у цитираном делу монографије, а у закључном делу то и експлицитно оправдава: Ни у једној од наведених граматика не помиғу се РЕЧЦЕ као пета непроменљива врста речи (Ранђеловић 2016: 375).

У другом делу ове тачке Јовановић испитује употребу и позицију речце не у односу на глагол и каже да часииица не, аще на глаголь возносийсл,

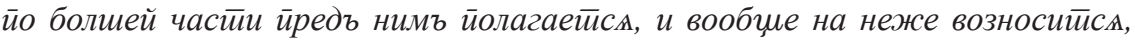

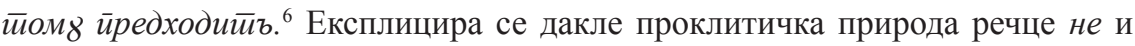
за то дају адекватни примери. Даље у тексту приказује две ситуације када је речца не раздвојена од глагола. У првој каже да бо, ктио, когда и какw, иног-

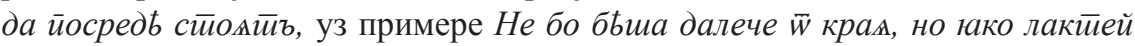

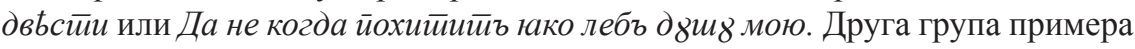
представља реченице у којима су услед инсистирања на постпонирању глагола у (славизираној) реченици негација и сам глагол још више удаљени једно од

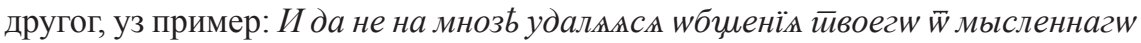
sвьродловленъ бдд8. Истиче се и специфичност упитних реченица у истом контексту, Не Їисуса Хрїсйа ли видьхъ? или Какш убо не и съ нимъ вся намъ дарсиивдетиъ? (исто: 282-283).

У десетој тачки се у кратким цртама говори о положају и типу дидаскалије у управном говору. „Њена је основна комуникативна улога да идентификује говорника пренесеног туђег говора, па зато њен граматички центар по правилу заузимају глаголи типа verba dicendi. [...] Ауторска дидаскалија може бити или у препозицији (и тада се иза ње обавезно ставља двотачка) или

\footnotetext{
${ }^{6}$ Јовановић, како видимо, ипак користи термин речца (частица), у овом случају и оправдано, али на нивоу целог рада апсолутно несистемски. Претходно смо видели да их не разликује јасно од везника (што је случај са доста граматичара тога времена), а доказ да му нису искристалисане као граматичка категорија је и то што их не наводи када набраја и анализира врсте речи у делу о морфологији ове граматике (Јовановић 1851: 13-162).
} 
у постпозицији, или пак у интерпозицији" (Ковачевић 2012: 16). Јовановић уводи глаголе истога типа (рече, глаголейъ и йоджбн.) и, иако истиче чешћу, уобичајену, препонирану (глаголску) употребу, даје примере и за препозицију и за интерпозицију, док изостају примери постпозиције дидаскалије. Примери које наводи и за ову манифестацију карактеристичног реда речи у реченици такође су изразито религиозног типа и поново су веома прецизно одређени,

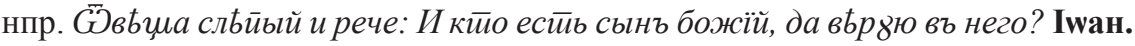
9, 36. (исто: 283).

Једанаеста тачка се састоји од тврдње у виду једне реченице изнете на почетку, Прембтеніе единагш реченїА далйъ различный раздмъ иредложенїю, ${ }^{7}$ и пет група примера којима се експлицира утицај реда речи на разумевање реченице, односно утицај промене редоследа реченичних конституената на реченични акценат, тиме и на њено разумевање. У појединим примерима аутор даје и претпостављено разумевање реченице условљено одређеним редом речи у њој. Онъ уииверждаетиъ, ғако движенїе и ничиио болье, иьлбу человькв

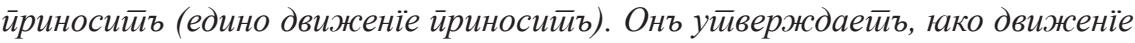

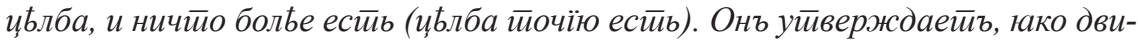

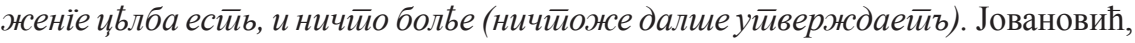
дакле, овде још једном (индиректно) повезује стилистику и синтаксу, истичући тиме додатно потребу за проучавањем синтаксичких и стилистичких својстава српскога језика и њихових међусобних утицаја на структурну стабилност и стилистичку флексибилност српске реченице, односно реченице (литературе) тога времена, а кроз призму неутралног, а затим и специфичног реда речи у њој (исто: 283). ${ }^{8}$

На самом крају овог одељка, у виду две напомене, иримьчания, Јовановић даје својеврсну сублимацију реченог о специфичностима реда речи у претходних једанаест тачака. Под бројем један даје дефиницију природног реда речи (мисли):

7 За наш рад је веома важно обратити пажњу на структуру саме реченице којом је ово правило дефинисано, односно на ред речи у њој. Наиме, и синтагматски и клаузални ред речи у потпуности одговарају уобичајеном, немаркираном реду речи у савременом српском језику. Структура реченичних конституената, иако сложених, одговара данашњем неутралном С - П - О редоследу. То даље може наводити на закључке да је, када је питању ред речи у реченици, језик граматичара (писаца) тога времена био доста ближи данашњем језичком стандарду и, прептоставимо, тадашњем народном језику, него језик литературе коју су читали, те језик литературе из које су цитирали примере за своје граматичке тврдње.

${ }^{8}$ Раније у тексту већ смо нагласили да прве сличне примере наглашавања потребе повезивања синтаксичких и стилистичких изучавања српског језика, овде конкретно кроз анализу реда речи, налазимо код Стојана Новаковића, у Посланици СКА, штампаној 37 година после Јовановићеве граматике. 
Єстественное теченїе мыслей требяетъ, да вопервыхъ изречетсл оно, w чемъ глаголати (подлежаце), а потомъ оно, еже ем8 приложити хоцемъ (сказдемо), таже wпредьленїА сегw. Всегда убо должно есть шпредьлАемо предходити шпредьленїю своем8 (Јовановић: 283-284).

Ауторова дефиниција је готово подударна са оним што пише Пера Ђорђевић, 45 година касније у йрисииуйној академијској беседи, када је Вукова реформа увелико прихваћена, а синтаксичка и стилистичка проучавања српског књижевног језика била готово уз раме са фонетском, морфолошком и лексичком, те правописном дескрипцијом и проскрипцијом језичког стандарда:

Одговарајући психолошком удруживању престава, и граматичко везивање речи у реченицу иде, природним путем, од познатога непознатом. У обичном, редовном, излагању мисли прва половина реченице казује ствар познату (,оно о чем се говори”), друга пак ствар нову, дотле непознату („оно што се о нечем говори”). [...] Другим речима, пре него што бисмо исказали психолошки прирок, треба објавити психолошки подмет ${ }^{9}$ (Ђорђевић 1898: 173-174).

Још једном су се, дакле, Јовановићева размишљања и дефинисања појединих синтаксичких појава, конкретно реда речи у српском језику, показала пионирским, за своје време изузетно иновативним. Подударност са дефиницијама у каснијим, нормом одређеним фазама српске синтаксе је јако велика. Аутор дефиницију проширује и прописивањем позиције реченичних одредаба, те њиховим међусобним редоследом. Иако није најјасније, с аспекта граматичке терминологије XIX века, шта покрива термин жйредбленїе, чини се да у Јовановићевом терминосистему он представља искључиво клаузалну конституентску одредбу. Јако мало је вероватно да би се значење термина могло поистоветити са оним што је дато у савременом руско-српском речнику за одредницу определение, као пето значење, са квалификатором лингв. - атрибут. Иако смо већ истакли специфичност синтагматског реда речи у језику ове епохе, иако је и сам Јовановић на почетку овог рада прописивао пожељну позицију придева (атрибута) у односу на именицу (центар), он у овим сублимирајућим дефиницијама и мислима о карактеристичном реду речи у српском (славенском) језику тај синтаксички проблем не разрађује. Дефиниција се заправо односи на објекат и различите глаголске одредбе и допуне. Прилог тој тврдњи јесу примери којима се покушава потврдити изнето правило, Госйоди, кйо

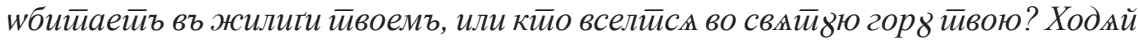
нейореченъ - глагольй истиинд въ сердиь своемъ. Скажи ми, госйоди, кончинд мою и число дней моихъ (кое естиь) да раздмею, чиио лимаюя азъ. Као што се види, на клаузалном плану ред речи скоро апсолутно одговара прописаном правилу, на првом месту је субјекат, следи предикат и за њим објекат (прави и неправи) те прилошке одредбе и допуне. На синтагматском, пак, плану ред

\footnotetext{
${ }^{9}$ Ђорђевић непосредно после ове реченице ограђује себе од употребе атрибута психолош$\kappa и$ уз субјекат и предикат говорећи да га навлаш уйойреблава и наглашава да у психолошком реду речи подмет (субјекат) не мора претходити прироку (предикату).
} 
речи није у складу са данашњим стањем у стандардном језику, већ, рекло би се, верно одсликава синтагматске инверзије карактеристичне за славеносрпски период: у вишечланој именичкој синтагми конгруентни атрибут посесивног типа доследно се постпонира у односу на центар синтагме, док су конгруентни атрибути квалитативног типа чешће у антепозицији.

До краја овог одељка Јовановић наглашава да је у природи одређених језика да не следе увек овакав, логичан и природан ред речи:

Обаче Азыкъ всегда не сльдяетъ семд тихом४, мирном8 логїческом8 рАдя, но слджить иногда многоразличнь и тмБнАемом8 израженїю чдвствованій и намБренїю глаголающагш. Єликш убогшь есть Азыкъ стройми грамматиїческими, толикш болше порабоџенъ и единошбразенъ есть союзъ реченій въ немъ. Сицевъ есть н.п. Франкогаллійскій Азыкъ, въ немже рАдъ реченій есть по болшей части строгш шпредьленъ (Јовановић 1851: 284).

У наставку истиче предности језика у којима је ред речи слободан, нарочито за поетски (уметнички) и реторички израз.

Во греческомъ, римскомъ (латїнскомъ) и славенскомъ Азыць логїческїй союзъ реченій есть шбезбьжденъ грамматиїческими реченїй видами; тогш ради Азыкъ ньть привАзанъ посльдованїю реченій словосочинителномя, и тьмъ полдчаетъ свободв, еже реченїА всегдашнемя чявствованїю, или умномя смотренїю, намБренїю сходнш разпорлдити, еже есть нешцБненна полза ради стїхотворца и витїи (исто: 284).

На почетку другог примьчанїя аутор констататује да је покушао да приложи неколикш йоне законшвъ ш йосльдованӥи реченій, жбаче всегда шбрбль, ғако йравило не жйравдаейсл йримбрми. Ипак, условно речено, утеху проналази у сличним проблемима са којима су се сретали синтаксичари латинског језика,

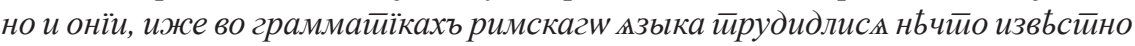
сказайи, малж усйьша. Још једном се Јовановић позива на стање у класичним језицима и њиховим граматикама. На више места у овом прилогу наглашавају се како сродности тако и разлике између класичних језика, грчког и латинског, и славенског, односно српског књижевног језика ауторова времена. Више пута истицана премиса је, како смо видели и раније у тексту, да српски језик, баш као и класични језици, за разлику од других (европских) језика, има релативно слободан ред речи у реченици.

У сличном маниру се и завршава овај одељак, са два правила, општеважећа, за која аутор сматра да су ипак изнад претходно поменутих проблема са дидактичким примерима. У првом говори о реченичном акценту и каже

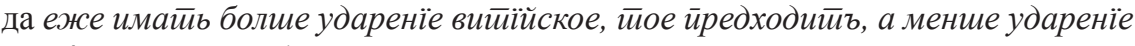
йосльддеиъ , наводећи пример: $Є с \bar{и} ь$ Богъ нашъ на небеси, емұже мы слджимъ. Истиче се да је реченични склад и овде постојећи, али да у преводу (на стилски немаркирани дискурс) сїе быти не можетъ и наводи пример реченице са

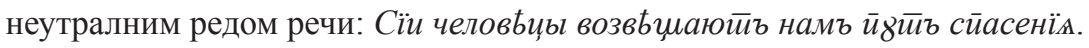


Остајући на пољу класичних језика аутор у другој напомени пак истиче да у Славяншвъ и Грекшвъ глаголь на краи не нұжднш йолагаейся, уз при-

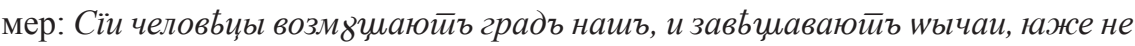

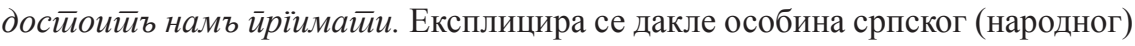
језика која је суштински супротна иманентној одлици славеносрпског језика, подразумевајућем постпонирању глагола. Уводи се синтаксичка паралела између српског и грчког, чиме се имплицитно аутор ограђује од стања у латинском језику. Данас важећа и већ помињана хипотеза јесте да је синтакса славеносрпског језика, односно језика књижевности краја XVIII и почетка XIX века, формирана уз снажан утицај руског (рускословенског), односно немачког, а суштински кроз њих управо латинског језика. Разрађујући до краја ову претпоставку, аутор наводи да је ред речи условљен, односно позиција

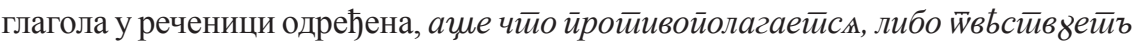
чему, те у упитним и заповедним реченицама, још једном се у великој мери подударајући са стањем у синтакси савременог језика, насталом на основама народног језика (исто: 284-285).

Кроз цео одељак о реду речи у својој граматици, а нарочито на самом његовом крају, Јовановић показује изванредан осећај за неутралан и природан ред речи у српском народном језику свога времена, као пожељном језичком моделу, али и неспособност да исти примени у свом научном дискурсу. Можемо претпоставити да је узрок томе својеврсни Јовановићев модел синтаксичког сигнализирања на функционално раслојавање језика, где би научни функционални стил био један од (виших) варијетета у којем би се задржале карактеристике славенскога (црквенословенког, а донекле, како смо видели, и славеносрпског) језика. То би на одређени, али прилично сигуран начин био доказ хипотезе да у народном говору најпрепознатљивије синтаксичке особине славеносрпског језика, постпонирање глагола и синтагматске инверзије, нису постојале или барем нису биле подразумеване.

\section{ИЗВОР:}

Јовановић 1851: Єvгенїе Ішановичъ, Граммайїка иерковно-славднскагш Азыка, Вїена: Иждывеніемъ Алберта А. Венедікта, книгопродавца славАнскагш. Въ тvпографїи арменскагш Монастыра. 


\section{ЛИТЕРАТУРА}

Бошковић 1864: Јован Бошковић, Извод из срйске грамайике, књига друга, IV.

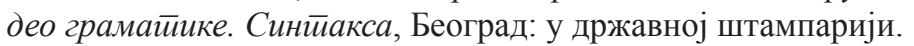

Видаковић 1838: Милованъ Видаковичъ, Граммайіка сербска или йаче кратикое йо исииытиословію у сербскій єзыкъ Руководстиво, Пешта: Писмены Іос. Баймела, Острогонскогъ Кньигопечателя.

Даничић 1858: Ђуро Даничић, Србска синйакса. Део йрвый, Београд: У државной штампаріи.

Ђорђевић 1898: Пера П. Ђорђевић, „О реду речи у српском језику”, (приступна аадемска беседа), Глас Српске краљевске академије, LIII, $167-231$.

Живановић 1889: Јован Живановић, Срйска синйакса, Нови Сад: Издање и штампа А. Пајевића.

Захаријадис 1832: ГеюргіА ЗахаріАдис, Славенска граммайіка, Будим: Писмены Кральвскога Всеठчилиџа Пештанскога.

Ивић 1971: Павле Ивић, Срйски народ и њихов језик, Београд: Српска књижевна задруга.

Ивић 1991: Павле Ивић, „Доситејевски књижевни језик између славеносрпског и вуковског”, Научни састианак слависйа у Вукове дане, 19/2, 5-14.

Јовановић 2013: Јелена Јовановић, Лингвистичкки и сииилистички асиекиии ироучавањ а реченице, Београд: Научно друштво за неговање и проучавање српског језика.

Јонке 1963: Ljudevit Jonke, „O redu riječi sa sintaktičkog i stilističkog gledišta u hrvatskosrpskom jeziku" u: Zbornik u čast Stjepana Ivšića, Zagreb: Hrvatsko filološko društvo, 171-182.

Ковачевић 1991: Милош Ковачевић, „Из проблематике развоја синтаксичких категорија: финалне конструкције у Доситејеву језику”, Научни састанак слависта у Вукове дане 19/2, 69-80.

Ковачевић 2002: Милош Ковачевић, Синтаксичка негаиија у српскоме језику, Ниш: Издавачка јединица Универзитета.

Ковачевић 2012: Милош Ковачевић, „О граматичко-стилистичком терминосистему туђег говора", Српски језик, Студије српске и словенске, XVII, 13-38.

Ковачевић ${ }^{42015: ~ М и л о ш ~ К о в а ч е в и ћ, ~ С т и л и с т и к а ~ и ~ г р а м а т и к а ~ с т и л с к и х ~}$ фигура, Београд: Јасен. 
Ковтунова 1969: Ирина Илынчина Ковтунова, Порядок слов в русском литаратурном языке, XVIII-первой трети XIX в., Москва: Академия наук СССР, Институт русского языка.

Милановић 2013: Александар Милановић, Језик весма полезан, Београд: Друштво за српски језик и књижевност Србије.

Милановић 2014: Александар Милановић, Језик Јована Суботића, Београд: Филолошки факултет.

Младеновић 1989: Александар Младеновић, Славеносрпски језик, Нови Сад: Књижевна заједница Новог Сада.

Мразовић 1794: Авраам Мразовичъ, Рдководсӣво къ славенсӣбй граммайій во уӣотиребленіе славено-себскихъ народныхъ училиґъ, Вїена: түпомъ г. Стефана Новаковича.

Новаковић ${ }^{2}$ 1870: Стојан Новаковић, Српска синтакса. За ниже гимназије и реалке Кнежевине Србије (друго прерађено и раширено издање), Београда: издање и штампа државне штампарије.

Новаковић ${ }^{4}$ 1880: Стојан Новаковић, Српска граматика за ниже гимназије и реалке у Кнежевини Србији, IV, Наука о реченицама (синтакса), Београд: Издање и штампа државне штампарије.

Новаковић 1888: Стојан Новаковић, „Српска краљевска акдемија и неговање језика српског, посланица академији наука философских, прочитана на свечаном скупу академије, држаном 10. Септембра 1888 у славу стогодишњице Вука Стеф. Караџића”, Глас Српске краљевске академије, X, Београд: Краљевско-српска државна штампарија, 1-88.

Петковић 1935: Сава Петковић, Речник црквенословенског језика, Сремски Карловци: Српска манастирска штампарија.

Пипер и др. 2005: Предраг Пипер, Ивана Антонић, Владислава Ружић, Срето Танасић, Људмила Поповић, Бранко Тошовић, Синтакса савременог српског језика, Проста реченища, Београд: Институт за српски језик САНУ, Београдска књига; Нови Сад: Матица српска.

Поповић 1997: Љубомир Поповић, Ред речи у реченици, Београд: Друштво за српски језик и књижевност Србије.

Ранђеловић 2016: Ана Ранђеловић, Језикословна терминологија код Срба у XIX веку, (докторска дисертација), Београд: Филолошки факултет.

PМC 1967-1976: Речник српскохрватског књижевног језика, I-VI, Нови Сад: Матица српска. 
PCP 1998: Руско-српски речник (у редакиији Богољуба Станковића), Нови Сад: Матица српска, Москва: Русский язык.

Силић 1984: Josip Silić, Od rečenice do teksta (teoretsko-metodološke pretpostavke nadrečeničnog jedinstva), Zagreb: Liber.

Симић 1991: Радоје Симић, О нашем књижевном језику, Никшић: НИП „Универзитетска ријеч”.

Симић/Јовановић 2002: Радоје Симић, Јелена Јовановић, Српска синтакса, I-II, Београд: Научно друштво за неговање српског језика.

Симић/Јовановић 2002: Радоје Симић, Јелена Јовановић, Српска синтакса, $I I I-I V$, Београд: Научно друштво за неговање српског језика.

Станојчић/Поповић ${ }^{82000: ~ Ж и в о ј и н ~ С т а н о ј ч и ћ, ~ Љ у б о м и р ~ П о п о в и ћ, ~ Г р а м а т и-~}$ ка српскога језика, Уибеник за I, II, III и IV разред средње школе, Београд: Завод за уџбенике и наставна средства.

Стевановић 1989: Михаило Стевановић, Савремени српскохрватски језик II, Синтакса, Београд: Народна књига.

Тошовић 2002: Бранко Тошовић, Функиионални стилови, Београд: Београдска књига.

Халупка-Решетар 2009: Sabina Halupka-Rešetar, „Red reči u službi izražavanja informacionog fokusa u srpskom jeziku", Зборник Матице српске за филологију и лингвистику, LII/2, 169-186.

Шћепановић 2011: Михаило Шћепановић, „Ред речи на размеђи основице и надградње српског језика", Српски језик, XVI, 505-512.

\section{ON WORD ORDER AS A SPECIFIC SYNTACTIC EXPONENT OF 19TH CENTURY LANGUAGE IN E. JOVANOVIĆ'S 1851 GRAMMAR OF THE OLD CHURCH SLAVONIC LANGUAGE}

\section{Summary}

The paper will present, analyse and theoretically consider word order as a specific syntactic exponent of 19th-century language in Evgenije Jovanović's 1851 Grammar of the Old Church Slavonic Language. We will try to ascertain to what extent the author's views coincide with the syntactic features of the Slavonic Serbian era, as well as to what extent they can be used to identify the syntactic features of the then vernacular Serbian, and indirectly those of the contemporary language expression.

Keywords: word order, syntax (sentence, phrase, attribute, verb), Old Church Slavonic, Slavonic Serbian, Serbian language, Slavic language. 